\title{
Strategi PT. Noor Abika Tour dalam Meningkatkan Kualitas Pelayanan Prima
}

\author{
Ainurrohmah $^{1 *}$, Sitty Sumijati ${ }^{2}$, Moch. Fakhruroji ${ }^{1}$ \\ 1 Jurusan Manajemen Dakwah, Fakultas Dakwah dan Komunikasi, \\ UIN Sunan Gunung Djati, Bandung \\ ${ }^{2} J u r u s a n$ Komunikasi dan Penyiaran Islam, Fakultas Dakwah dan Komunikasi, \\ UIN Sunan Gunung Djati, Bandung \\ *Email : eenainurrobmab4@gmail.com
}

\begin{abstract}
ABSTRAK
Tulisan ini bertujuan untuk mengetahui perencanaan pelayanan, penerapan pelayanan, dan evaluasi pelayanan PT. Noor Abika Tour Travel. Penelitian ini termasuk penelitian kualitatif yang mengambil lokasi PT. Noor Abika Tour Travel dengan menggunakan pendekatan diskriptif. Adapun metode pengumpulan data yang digunakan yaitu metode observasi, wawancara, dan dokumentasi. Hasil dari penelitian menunjukan proses Perencanaan Pelayanan PT. Noor Abika Tour menggunakan strategi manajemen yang meliputi: Pertama, strategi pengembangan produk. Kedua, strategi penerapan harga. Ketiga, strategi pengembangan pasar. Sedangkan penerapan Pelayanan PT. Noor Abika Tour Travel adalah memberikan apa yang dibutuhkan oleh para jamaah haji selama mereka menjalankan ibadah haji baik ketika masih di tanah air maupun di tanah suci. Evaluasi Pelayanan PT. Noor Abika Tour Travel dalam pelayanan haji menghasilkan pelayanan yang di kategorikan memuaskan jamaah baik di tanah air maupun di tanah suci hingga pulang ke tanah air.
\end{abstract}

Kata Kunci: Strategi; Manajemen; Pelayanan Prima

\section{ABSTRACT}

This paper aims to find out the service planning, service implementation, and evaluation services performed by PT. Noor Abika Tour Travel. This research includes qualitative research that takes the location of PT. Noor Abika Tour Travel using a descriptive approach. The data collection method used is the method of observation, interview, and documentation. The results of the research show the process of Service Planning PT. Noor Abika Tour uses a management strategy that includes: First, product development strategy. Second, pricing strategy. Third, market development strategy. While the application of PT. Noor Abika Tour Travel is giving what is needed by the pilgrims during their pilgrimage when they are still in the country or in the boly land. The evaluation of PT. Noor Abika Tour Travel in service of Hajj resulted in a satisfactory for congregation wants in both the homeland and the holy land to return home.

Keywords: Strategy; Management; Excellent Service 


\section{PENDAHULUAN}

Pelayanan merupakan atau kegiatan/keuntungan yang di tawarkan oleh organisasi atau perorangan kepada konsumen (costomer) yang bersifat tidak terwujud dan tidak dapat dimiliki. Oleh karena perlu upayan peningkatan pelayanan kepada masyarakat. Pelayanan kepada masyarakat inilah yang biasa di sebut pelayan publik atau pelayanan umum, dalam memberika pelayanan pemerintah harus memperhatikan keinganan masyarakat sebagai pelanggang. Kualitas pelayanan sangat mempengaruhi proses perbaikan efektifitas organisasi. Hasil study menunjukan bahwa perusahaan yang menerapkan strategi kualitas pelayanan memiliki pengaruh yang positif terhadap kinerja perusahaan baik untuk saat ini dan masa depan. Untuk itu reputasi kualitas perusahaan yang baik harus menekankan pada prioritas strategi sehingga dapat meningkatkan net operating income atau growth tidak hanya dalam jangka pendek tetapi juga jangka panjang.

PT. Noor Abika Tour Travel sebuah perusahaan yang penyedia layanan transportasi dengan pelayan prima dan penyelenggaraan ibadah haji khusus dengan pelayanan yang terbaik dan profesional. Dalam mempelanyani para calon jamaah haji PT. Noor Abika Tour Travel mempunyai perlindunga pelayanan yang dimana perlindungan itu dari segi hukum, pelindungan asuransi, jaminan kepastian dan tanggung jawab perusahaan sebelum keberangkatan ke tanah suci. Sedangkan dalam fasilitas pelayanan PT. Noor Abika Tour Travel mempunyai fasilitas pelayanan mulai dari pesawat, hotel, transportasi, makan, pembimbing ibadah, guide/muthawwif, tour leader dan petugas kesehata. Fasilitas itu akan diberikan kepada para calon jamaah haji untuk berangkat ke tanah suci. Sebagai salah satu perusahaan travel PT. Noor Abika Tour Travel yang mempunyai peran penting dalam melayani calon jamaah haji, maka diperlukan suatu strategi yang baik.

Dari latar belakang masalah tersebut dapat dirumuskan beberapa masalah: Bagaimana perencanaan pelayanan yang dilakukan PT. Noor Abika Tour? Bagaimana penerapan pelayanan yang dilakukan PT. Noor Abika Tour Travel? Bagaimana evaluasi pelayanan yang dilakukan PT. Noor Abika Travel.?

Penelitian ini dilakukan pada PT. Noor Abika Tour Travel yang berada di Graha Panyileukan Asri, ruko No. 18-19 Jl. Soekarno Hatta No.766 , Bandung. Tujuan Penelitian yang hendak dicapai melalui penelitian ini, pertama, untuk mengetahui perencanaan pelayanan yang di lakukan oleh PT. Noor Abika Tour Travel. Kedua, untuk mengetahui penerapan pelayanan yang di lakukan PT. Noor Abika Tour Travel. Ketiga, untuk mengetahui evaluasi pelayanan yang dilakukan oleh PT. Noor Abika Tour Travel.

Metode penelitian yang digunakan adalah Metode deskriptif ini bertujuan untuk menjawab pertanyaan tentang perencanaan, penerepan dan evaluasi (Husein Umar, 2004:22). Dan memamparkan dan menjelaskan data-data informasi tentang pelayanan prima yang digunakan oleh PT. Noor Abika Tour Travel dalam pelayanan terhadap jama'ah haji melalui observasi, wawancara dan studi kepustakaan yang menyeluruh terhadap objek penelitian. kemudian, data yang telah diperoleh dan dianalisis. Dengan mengggunakan metode tersebut dapat 
menghantarkan peneliti dalam peroleh data secara benar, akurat dan lengkap berdasarkan pengumpulan data dan pengelolaan data secara sistematis.

Jenis data yang digunakan dalam penelitian ini adalan kualitatif. Penelitian kualitatif adalah suatu penelitian ilmiah yang bertujuan untuk memahami suatu fenomena dalam konteks sosial secara alamiah dengan mengedepankan proses interaksi komunikasi yang mendalam antara peneliti fenomena yang diteliti (Hardiansyah, 2011 : 9). Jeni data yang dikumpulkan dalam penelitian ini merupakan jawaban atas beberapa pertanyaan penelitian yang diajukan terhadap masalah yang dirumuskan pada tujuan yang telah ditetapkan. Adapun jenis data tersebut diklasifikasikan sebagai berikut : Pertama, data yang berhubungan dengan perencanaan pelayanan yang dilakukan PT. Noor Abika Tour Travel; Kedua, data yang berhubungan dengan penerapan pelayanan yang dilakukan PT. Noor Abika Tour Travel; Ketiga, data yang berhubungan dengan evaluasi pelayanan yang dilakukan PT. Noor Abika Tour Travel.

Sumber data yang digunakan peneliti terdiri dari sumber data primer dan sumber data sekunder. Pertama, sumber data primer adalah sumber data dari hasil informasi tertentu tentang sesuatu data dari seseorang tentang masalah yang sedang akan diteliti oleh seorang peneliti (Sadiah, 2014:93). Yaitu tentang strategi pelayanan prima diperoleh langsung dari wawancara bersama para informan yang terdiri dari staf atau karyawan di PT. Noor Abika Tour Travel. Kedua, Sumber data sekunder adalah ragam kasus baik berupa orang, barang yang menjadi sumber informasi penunjang yang berkaitan dengan masalah penelitian. Data sukender ini dapat melengkapi pemahaman peneliti dalam menganalisis data ini disebutkan peneliti secar rinci sesuai dengan lingkup masalah yang ditelitinya. (Dewi Sadiah, 2014:94).

Analisis data dalam penelitian kualitatif yaitu pengumpulan data (data collection), verifikasi dan penegasan kesimpulan.Pertama, Pengumpulan data merupakan bagian integral dari kegiatan analisis data. Kegiatan pengumpulan data pada penelitian ini adalah dengan menggunakan wawancara dan studi dokumentasi. Kedua, Membuat kesimpulan dan verifikasi. (Sugiyono, 2013:252). Langkah ketiga dalam data kualitatif menurut Miles dan Huberman (Sugiyono, 2012 : 252) adalah penarikan kesimpulan dan verifikasi. Dalam penelitian ini peniliti melakukan penarikan kesimpulan terhadap data-data yang diperoleh dari lapangan, peneliti juga memastikan bahwa data-data atau informasi tersebut merupakan data-data yang kredibel. Selanjutnya data yang telah dianalisis, dijelaskan dan dimaknai dalam bentuk kata-kata untuk mendiskripsikan fakta yang ada di la pangan, pemaknaan atau untuk menjawab pertanyaan penelitian yang kemudian diambil intisarinya.

Berdasarkan keterangan di atas, maka setiap tahap dalam proses tersebut dilakukan untuk mendapatkan keabsahan data dengan menelaah seluruh data yang ada dari berbagai sumber yang telah didapat dari lapangan dan dokumen pribadi, dokumen resmi, gambar, foto dan sebagainya melalui metode wawancara yang didukung dengan studi dokumentasi. 


\section{LANDASAN TEORITIS}

Teori yang dijadikan landasan dalam penelitian ini adalah teori strategi, pelayanan prima dan haji plus. Kata strategi berasal dari Yunani, yaitu stratogos atau strategis yang berarti jendral. Strategi berarti seni jendral. Maka startegi kalau diartikan dari sudut militer adalah cara menempatkan pasukan atau menyusun kekuatan tentara di medan perang agar musuh dapat dikalahkan (Saladin, 2011:1).

Glueck William F. dan Jauch Lawrence R, (dalam Saladin, 2011:1) yang mendefinikan bahwa strategi adalah sebuah rencana yang disatukan, luas dan terintegrasi, yang menghubungkan keunggulan strategik perusahaan dengan tantangan lingkungan dan yang dirancang untuk memastikan bahwa tujuan utama perusahaan dapat dicapai melalui pelaksanaan yang tepat oleh organisasi.

Proses strategi Seperti yang dikatakan oleh Joel Ross dan Michael yang dikutip dari David (1998 : 6) bahwa sebuah organisasi tanpa adanya strategi umpama kapal tanpa adanya kemudi, bergerak, berputus dalam lingkaran. Adapun proses strategi terdiri dari tiga tahap : Pertama, Perencanaan Strategi. Dalam perencanaan strategi termasuk didalamnya, adalah pengembangan tujuan, mengenali peluang dan ancaman eksternal, menetapkan suatu objektifitas, menghasilkan strategi alternatif memilih strategi untuk dilaksanakan. Dalam perencanaan strategi juga ditentukan suatu sikap untuk memutuskan, memperluas, menghindari atau melakukan suatu keputusan dalam suatu proses kegiatan. Kedua, Penerapan Strategi.

Penerapan strategi merupakan suatu proses yang dinamis, berurutan dan kompleks yang terdiri dari serangkaian tindakan dan aktivitas yang dilakukan oleh manajer dan para karyawan yang dipengharui oleh sejumlah faktor internal dan eksternal yang saling berhubungan dengan tujuan mengubah berbagai rencana strategis menjadi suatu kenyataan untuk mencapai suatu tujuan perusahaan. Ketiga, evaluasi Strategi adalah tahap akhir strategi, ada beberapa macam aktivitas mendasar untuk mengevaluasi strategi diantaranya : pertama, meninjau faktorfaktor eksternal (berupa peluan dan ancaman), faktor-faktor internal (kekuatan dan kelemahan) yang menjadi dasar asumsi pembuatan strategi. Kedua, mengukur prestasi membandingkan hasil yang diharapkan dengan kenyataan. Ketiga, mengambil tindakan yang korektif untuk memastikan bahwa prestasi sesuai dengan rencana.

Dari beberapa strategi yang diungkapkan oleh para ahli di atas, ini sejalan dengan strategi yang dilakukan oleh Nabi Muhammad S.A.W. Ali Mufrodi dalam tulisannya Sejarah dan Dakwah Nabi saw, ada dua rahasia dari strategi kesuksesan dakwah Nabi saw, yaitu nilai konsistensi dan nilai keteladanan. Yang dimaksud nilai konsistensi adalah: Pertama, bahwa Nabi saw selalu istiqomah, tetap pada pendirian, tanpa mengenal putus asa untuk terus berdakwah kendatipun berbagai tantangan, godaan, bujukan sampai kepada teror sering ia hadapi, kedua, bahwa Nabi saw konsekuen dengan apa yang diucapkan/didakwahkannya tanpa harus menarik kembali apa yang didakwahkannya karena memandang dirinya belum mampu/enggan mempraktekannya. Ketiga, adanya kesesuaian antara apa yang 
diucapkan dengan apa yang ia perbuat, demikian pula sebaliknya apa yang ia perbuat itulah yang ia katakan (Syamsudin, 2009 : 798).

Pengertian pelayanan adalah serangkaian aktivitas yang bersifat tidak kasat mata (tidak dapat diraba) yang terjadi sebagai akibat adanya interaksi antara konsumen dengan karyawan atau hal-hal lain yang disediakan oleh perusahaan pemberi pelayanan yang dimaksudkan untuk memecahkan permasalahan konsumen/pelanggang (Winarsih dan Ratminto, 2013:2). Menurut Cathering De Vrye (2013:20) yang mengolah kata service untuk dikaitkan dengan langkahlangkah strategi untuk menuju kesuksesan yang disebutnya "Tujuh Strategi Sederhana Menuju Sukses" S.E.R.V.C.E itu dipanjangkan dalam istilah dan makna sebagai berikut:

Pertama, Self Esteem : penilaian individu terhadap kehormatan diri, melalui sikap terhadap dirinya sendiri yang sifatnya implisit dan tidak diverbalisasikan dan menggambarkan sejauh mana individu tersebut menilai dirinya sebagai orang yang memiliki kemampuan, keberartian, berharga, dan kompeten.

Kedua, Exceed Expectation :melampaui yang diharapkan konsumen, baik berupa barang atau jasa. Ketiga, Recover: merebut kembali dari sesuatu yang hilang yang mempengaruhi proses pelayanan dari perusahaan terhadap pelanggan. Keempat, Vision : merupakan tujuan jangka panjang yang ingin dicapai oleh perusahaan.

Kelima, Improve: melakukan peningkatan terhadap pelayanan yang diberikan terhadap pelanggan. Keenam, Care : memberi perhatian terhadap segala bentuk keinginan pelanggan, baik berupa kebutuhan, keluhan maupun feedback dari pelanggan. Ketujuh, Empower: memberikan pemberdayaan terhadap potensi yang sudah dimiliki oleh pelanggan.

Definisi pelayanan prima tersebut minimal harus ada tiga pokok, yaitu adanya pendekatan sikap yang berkaitan dengan kepedulian terhadap pelanggan, upaya melayani dengan tindakan terbaik, dan ada tujuan untuk memuaskan pelanggan dengan berorientasi pada standar pelayanan tertentu. Bahwa pelayanan prima adalah kepedulian kepada pelanggang dengan memberikan pelayanan terbaik untuk memfasilitasi kemudahan pemenuhan kebutuhan dan mewujudkan kepuasannya, agar mereka selalu loyal kepada organisasi/ perusahaan (Barata, 2003:27).

Pelayanan prima adalah pelayanan yang sangat baik melampaui harapan pelanggan. Pelayanan prima adalah pelayanan yang memiliki ciri khas kualitas yang baik meliputi, kemudahan, kecepatan, ketepatan, kehandalan dan emphaty dari petugas pelayanan dalam pemberian dari petugas pelayanan dalam pemberian dan penyampaian pelayanan kepada pelanggang yang berkesan kuat yang dapat langsung dirasakan pelanggan waktu itu dan saat itu juga (Rahmayanti, 2010:17).

Secara etimologi kata haji berasal dari bahasa Arab yang bermakna tujuan dan dapat dibaca dengan dua lafazh Al-hajj dan Al-hijj yang berarti maksud atau tujuan.

Sedangkan Haji menurut istilah Syar'i adalah beribadah kepada Allah dengan 
melaksanakan manasik yang telah ditetapkan dalam sunnah Rasulullah SAW. Namun ada pula ulama yang berpendapat : Haji adalah berpergian dengan tujuan ketempat tertentu pada waktu yang tertentu untuk melaksanakan suatu amalan yang tertentu pula. Akan tetapi defini ini kurang pas karena haji lebih khusus dari apa yang didefinisikan, karena seharusnya ditambah dengan satu ikatan yaitu ibadah, maka apa yang ada pada definisi pertama lebih sempurna dan menyeluruh. Atau bahasa yang lebih mudah dipahami haji adalah menuju Ka'bah untuk beribadah dengan melakukan beberapa perbuatan yaitu ihram, wukuf, thawaf, sa'i dan lainnya pada waktu yang telah ditetapkan (Saefudin, 2006:7).

Selain haji regular, pemerintah juga memberlakukan dan mengizinkan adanya ketentuan haji khusus (BPIH Khusus). BPIH untuk haji khusus (ONH Plus) ditetapkan oleh pemerintah lebih tinggi daripada haji regular, karena adanya perbedaan yang signifikan atas fasilitas yang diperoleh dan dinikmati oleh para jamaah. Untuk menyelenggarakan haji khusus, pemerintah melalui Departemen Agama bekerja sama dengan pihak swasta, yakni perusahaan penyelenggara haji khusus dan umrah yang telah mendapat izin dari Departemen Agama. Berdasarkan data Departemen Agama tahun 2006. saat itu di Indonesia terdapat 223 perusahaan penyelenggara ibadah haji dan umrah yang telah mendapat izin. (Rosadi, 2013: 71).

\section{HASIL DAN PEMBAHASAN}

PT. Noor Abika Tour dan Travel adalah salah satu perusahaan yang bergerak dalam usaha perjalanan wisata, tiket dan islamic tour (Umrah dan Haji), secara operasional mulai aktif sejak tahun 1985, pada awalnya para karyawan hanya menjalankan marketing Jemaah haji dan umrah untuk diberangkatkan, selain itu para karyawan juga menerima pembuatan dokumen seperti paspor, visa dan lainlain. Pada tahun 2001 PT. Noor Abika Tours Travel secara resmi didirikan dan memiliki akta notaris yang didirkan di Banjarmasin, baru pada tahun 2009 PT. Noor Abika Tours \& Travel mulai beroperasi secara resmi di Kota Bandung. Sang pemilik perusahaan H. Holil Aksan Umarzen berhak atas kepemilikan penuh perusahaan dan memiliki kantor di Bandung, Jawa Barat.

Visi dari PT. Noor Abika Tour Travel Menjadi perusahaan terbesar dan terbaik di Indonesia dalam bidang pelayanan perjalanan wisata domestik dan internasional dengan kualitas pelayanan yang profesional. Sedangkan dari misi yang diusung PT. Noor Abika Tour Travel diantaranya : Pertama, menjadi perusahaan penyedia layanan transportasi dengan pelayanan yang prima. Kedua, menjadi perusahaan yang mengedepankan kenyamanan, keamanan dan kepuasan pelanggan. Ketiga, menjadi perusahaan penyelenggara ibadah umrah dengan pelayanan terbaik dan profesional. Keempat, menjadi perusahaan penyelenggara ibadah haji khusus dengan pelayanan terbaik dan profesional. Kelima, menjadi perusahaan layanan jasa pariwisata yang tangguh dan unggul dengan jaringan mitra kerja yang tersebar di seluruh Indonesia.

Adapun dari program kegiatan yang dilakukan PT. Noor Abika Tour 
Travel dalam melaksanakan program perjalanan haji khusus diantaranya, memfasilitasi keinginan jama'ah dengan membuat beberapa komitmen dan program, diantaranya selalu melayani jamaah untuk mendapatkan kenyamanan selama beribadah, baik dari segi akomodasi, kosumsi, dan transportasi. Para jamaah haji tidak hanya mendapatkan pelayanan selama di tanah suci saja, tetapi di tanah air pun tetap mendapatkan pelayanan yang memuaskan, antara lain dengan beberapa kali manasik teori dan lapangan ( PT. Noor Abika Tour Travel, Buku Pedoman Kerja Travel Haji dan Umrah Noor Abika ).

Sejalan dengan keterangan tersebut, dalam wawancara dengan salah seorangan manajer PT. Noor Abika Tour Travel pada tanggal 20 September 2016 menyatakan bahwa manasik teori biasa dilakukan empat bulan sebelum pemberangkatan, dilaksanakan sepeluh kali pertemuan dalam tujuh kali bimbingan dalam seminggu sekali dengan materi yang berbeda-beda dengan manateri manasik haji diantaranya, aqidah, ibadah, akhlak, bahasa arab praktik dan kondisi arab saudi dan materi disampaikan oleh pembimbing ibadah haji yang turut serta pada program haji tersebut.

Sementara itu untuk manasik lapangan, beliau menjelaskan bahwa manasik lapangan dilakukan kurang lebih satu bulan sebelum keberangkatan. Dalam pelaksanaannya manasik lapangan memakan waktu kurang lebih dua hari satu malam. Manasik lapangan merupakan simulasi program haji di tanah suci. Adapun untuk program perjalanan haji khusus yaitu dilakukan selama 26 hari di tanah suci, dengan program arbain dalam menunaikan haji ke Padang Arafah serta melaksanakan sholat 40 waktu di masjid nawabi di kota madinah merupakan misi hamba Allah. Di Mekah dan Madinah tidak lupa berziarah ke tempat-tempat yang mempunyai nilai historis, program ini lebih lama dari program non arbain.

Hasil penelitian ini menemukan tentang perencanaan pelayanan, penerapan pelayanan dan evaluasi pelayanan yang di lakukan PT. Noor Abika Tour Travel.

\section{Proses Perencanaan Pelayanan PT. Noor Abika Tour Travel}

Pelayanan prima (Excellent Service) yang ada PT. Noor Abika Tour Travel merupakan salah satu bentuk kegiatan yang sangat diutamakan dalam penyelenggaraan ibadah haji. Dalam sebuah pelayanan tentunya dibutuhkan sebuah perencanaan sehingga mampumemberi pelayanan yang memuaskan bagi calon jama'ah haji. Dalam rangka mempertahankan pelayanan yang memuaskan sebuah organisasi memerlukan sebuah perencanaan.

Pada dasarnya proses perencanaan merupakan sejumlah kegiatan yang telah ditentukan sebelumnya untuk dilaksanakan pada suatu tertentu dalam rangka mencapai tujuan yang telah ditetapkan. Perencanaan merupakan penetapan misi perusahaan, penetapan sasaran organisasi, dengan mengikat kekuatan eksternal dan internal,perumusan kebijakan dan perencanaan tentu untuk mencapai sasaran dan memastikan implementasinya secara tepat, sehingga tujuan dan sasaran organisasi akan tercapai. Perencanaa dibangun dengan kualitas layanan karena perencanaan adalah suatu alat untuk mencapai suatu tujuan perusahaan.

Terdapat beberapa hal yang harus diperhatikan dalam membuat 
perencanaan untuk perbaikan pelayanan di PT. Noor Abika Tour Travel dalam upaya peningkatan pelayanan prima (Excellent Service) bagi calon jama'ah haji. Dalam memahami perencanaan yang dikembangkan oleh PT. Noor Abika Tour Travel penulis menggunakan tipe perencanaan trategi yang meliputi perencanaan pengembangan produk. penerapan harga dan pengembangan pasar (Wawancara dengan Divisi Haji dan Umrah PT. Noor Abika Tour Travel "Bapak H. Asep Komarudin" pada tanggal 20 September 2016).

Adapun strategi yang diterapkan dalam upaya peningkatan kualitas pelayanan prima (Excellent Service) di PT. Noor Abika Tour Travel menggunakan strategi manajemen yang meliputi beberapa aspek diantaranya adalah sebagai berikut:

Pertama, Perencanaan pengambangan produk, dalam memberikan pelayanan prima (Excellent Service) kepada calon jama'ah haji yang pertama dilakukan adalah pengembangkan prodok PT. Noor Abika Tour Travel diantanya: pertama, agent penjualan tiket transportasi domestik maupun internasional. Kedua, penyelenggaraan paket wisata domestik dan internasional. Ketiga, menyelenggarakan perjalanan ibadah haji plus dan umrah (izin resmi KEMENAG) izin haji Nomor: D/341 Tahun 2014, izin umrah nomor: D/143 tahun 2013, izin kementrian agama: PHU/HK.315/IV/2015. Keempat, pengurusan dokumen perjalanan wisata dan penyelenggaraan paket wisata lainnya.

PT. Noor Abika Tour Travel memiliki beberapa agen yang tersebar di hampir seluruh wilayah Indonesia, seperti Aceh, Palembang, Pangkalpinag Belitung, Banten, Palangkaraya, Banjarmasin, Surabaya, Semarang, Jogja, Madura, Makasar sampai ke Papua, dan sudah memiliki 4 cabang resmi, diantaranya: Pertama, PT. Noor Abika Tour Travel cabang Jakarta. Kedua, PT. Noor Abika Tour Travel cabang Antapani. Ketiga, PT. Noor Abika Tour Travel cabang Palembang. Keempat, PT. Noor Abika Tour Travel cabang Makasar.

Salah satu pengembangan produk yaitu dalam penyelenggaraan haji yang dimana sebelum perjalanan haji dilakukan penyelenggaraan manasik sebanyak 10 kali pertemuan, dalam bimbingan manasik haji kalau dikelompokkan pembimbing tidak merasa kesulitan dan waktunya tidak terlalu singkat dan bertambah banyak sehingga calon jama'ah haji akan paham dengan waktu yang lama. Dalam pengelompokkan tersebut, pembinaan manasik yang dilakukan PT. Noor Abika Tour Travel berhasil dengan lancar (Wawancara dengan Divisi Haji dan Umrah PT. Noor Abika Tour Travel "Bapak H. Asep Komarudin" pada tanggal 20 September 2016).

Kedua, penerapan harga, penerapan harga memiliki fungsi yang sangat luas didalam program pemasaran. Penerapan harga berarti bagimana mentautkan produk dengan aspirasi sasaran pasar, yang berarti pula harus mempelajari kebutuhan, keinginan dan harapan konsumen.

Untuk penerapan harga pihak PT. Noor Abika Tour Travel memberikan kemudahan bagi para calon jama'ah dalam melakukan transaksi pembayaran. Pada setiap tahunnya harga berubah pada tahun 2014 harga ONH Plus sebesar US\$ 8. 
500, Ketika jama'ah belum membuka buku tabungan haji plus (ONH PLUS) maka dari pihak PT. Noor Abika Tout Travel akan membukakannya dengan ketentuan membayar uang muka sebesar US\$ 4.500 dengan harga US\$ 9500. Pembayaran transfer bisa melaui bank-bank yang telah ditentukan oleh Kementrian Agama. Pendaftaran bisa dilakukan kapan saja baik melalui online ataupun datang langsung ke kantor Noor Abika Tour Travel pada jam kerja yaitu kapan saja akan dilayani kecuali pada tengah malam (Wawancara dengan Bapak H. Asep Komarudin pada tanggal 20 September 2016).

Ketiga, pengembangan pasar, mengembangkan sistem pemasaran yang door to door atau melalui link. Pengembangan pasar ini Noor Abika Tour Travel terus dilakukan dengan cara dari mulutke mulut karena Noor Abika Tour Travel mengukurnya menggunakan kepercayaan setiapjama'ah dengan kepuasan pelayanan yang diberikan (Wawancara dengan Bapak H. Asep Komarudin pada tanggal 20 September 2016).

\section{Penerapan Pelayan Prima PT. Noor Abika Tour Travel}

Salah satu kegiatan yang dilakukan oleh PT. Noor Abika Tour Travel adalah melaksanakan penyelenggaraan pelayanan prima (Excellent Service) pada calon jama'ah haji. Dalam hal ini tugas dari penyelenggaraan adalah memberikan pelayanan kepada calon jama'ah haji di PT. Noor Abika Tour Travel. Dalam pelaksanaan ibadah haji di PT. Noor Abika Tour Travel, ada beberapa hal yang perlu diperhatikan dalam pelayanan ibadah haji. Penyelenggaraan ibadah haji perlu adanya sebuah pelayanan yang tepat dan efektif, sehingga dalam pelaksanaan kegiatan dapat berjalan dengan lancar sesuai dengan tujuan yang telah ditentukan.

Adapun beberapa hal yang mempengharui terhadap proses pelaksanaan kegiatan penyelenggaraan ibadah haji adalah sebagai berikut:

Pertama, dasar penyelenggaraan PT. Noor Abika Tour Travel.

Adapun dasar pijakan dari pelaksanaan ibadah haji sebagai berikut: Pertama, keputusan Ka. Kanwil Departemen Agama Provinsi Jawa Barat Nomor: PUH / HK.3145 / VI / 2012 tentang penetapan kembali izin biro perjalanan wisata PT. Noor Abika Tour Travel sebagai penyelenggara haji khusus. Kedua, Keputusan direktur jendral Penyelenggaraan Haji Nomor: D / 341 / 2014 tentang pemberian Perpanjangan Ijin Operasional kepada wisata PT. Noor Abika Tour Travel. Ketiga, keputusan direktur jendral Penyelenggaraan Umroh Nomor: D / 768 / 2013 tentang pemberian Perpanjangan Ijin Operasional kepada wisata PT. Noor Abika Tour Travel. Keempat, Surat perjanjian / kesepakatan peserta dengan pengurus PT. Noor Abika Tour Travel (Dokumen PT. Noor Abika Tour Travel).

Kedua, fasilitas. Dalam menjalankan tugas penyelenggaraan pelayanan ibadah haji menempati sebuah ruangan yang telah disediakan oleh PT. Noor Abika Tour Travel, yang beralamatkan di Graha Panyieulekan Asri, Ruko No. 18-19 Jl. Soekarno Hatta, Bandung - Jawa Barat. Untuk bisa menjalankan tugasnya dengan baik dan lancar maka harus didukung dengan adanya fasilitas yang baik pula. Adapun fasilitas yang dimiliki oleh PT. Noor Abika Tour Travel yaitu: Pertama, hukum para jamaah yang terdaftar di PT. Noor Abika berhak dilindungi oleh 
hukum Indoneisa dan hukum Negara kerajaan saudi Arabian selama di Tanah Suci, sesuai legalitas dan perijinan perusahaan dan ketentuan serta syarat yang ditempuh oleh perusahaan dalam hal pelaksanaan ibadah menurut undang-undang dan ketentuan yanng di berlakukan oleh pemerintah Indoneisa, Kemenag R.I dan pemerintah Arab Saudi. Kedua, penasehat hukum, apabila terjadi perselisihan atau sengketa, maka di selesaikan secara musyawarah terlebih dahulu dengan melibatkan kuasa hukum yang di tunjuk oleh perusahaan. Ketiga, perlindungan asuransi, para jamaah berhak atas perlindungan pelayanan, kesehatan, kecelakaan dan lain-lain dari asuransi perlindungan pelayanan Umrah dan Haji sesuai polis dan ketentuan dari pihak asuransi terkait. Keempat, asuransi adalah perusahaan asuransi bertaraf Internasional yang berkedudukan kantor Saudi Arabia dan memiliki perwakilan atau bekerja sama dengan perusahaan asuransi Indonesia. Kelima, jaminan kepastian hak dan tanggung jawab, setelah kewajibannya terpenuhi, maka para jamaah berhak untuk mendapatkan jaminan dan kepastian sebagai tanggung jawab perusahaan sebelum keberangkatan ke Tanah Suci.

Ketiga, pembinaan jamaah haji di PT. Noor Abika Tour Travel adalah tahap bimbingan terhadap calon jamaah haji yang di laksanakan di Tanah Air dan Tanah Suci. Satu, pembimbing pra ibadah haji, bimbingan secara terpadu dengan materi : aqidah dan akhlak, tharah dan shalat, ibadah di madinatul munawarah dan ziarah, ibadah haji dan umrah serta rangkain ibadah di madinah al mukaromah, pembina rombongan atau regu, kesehatan jamaah haji, pembinaan haji di tanah suci.

Bimbingan haji di tanah suci dilaksanakan oleh para pembimbing yang telah mengikuti penataran pelatihan calon haji yang diselenggarakan oleh Ka. Kanwil provinsi Jawa Barat serta telah lulus psikotest yang telah dilaksanakan di PT. Noor Abika Tour Travel. Adapun bimbingan di tanah suci dilaksanakan dalam 2 tahap: Satu, pra ibadah dengan materi manasik haji yang dilaksanakan di halaman Masjid Nabawi di Madin tiap ba'da subuh selama 80 menit disertai dengan dialog interaktif. Pada saat menanti wuquf jama'ah dianjurkan untuk sholat berjama'ah di Masjidil Haram, memperbanyak istigfar, do'a serta tadarus Al-Qur'an. Dua, bimbingan ibadah haji dilaksanakan pada saat haji pembimbing di mulai dengan: Satu, mengenakan pakaian ihram, sholat sunnah di Bir Ali, melafalkan niat umrah mengumandangkan talbiyah sepanjang $498 \mathrm{~km}$ sampai di Makkah. Dua, membimbing do'a melihat ka'bah. Tiga, membimbing thowaf umrah di sertai larilari kecil pada putaran ke 1 sampai dengan ke 3 mulai dari hajar aswad sampai ke hajar aswad, sedangkan putaran ke 4-7 tanpa amalan. Empat, membimbing sholat sunnah ba'dal Thowaf dibelakang maqom Ibrahim, dilanjutkan dengan bimbingan do'a ba'da sholat secara bersama-sama. Lima, Membimbing do'a disaat minum air zam-zam. Enam, membimbing Sa'i disertai dengan bimbingan do'a secara terpimpin diikuti oleh jama'ah kemudian ditutup dengan bimbingan do'a bukit Marwa setelah sa'i selesai. Do’a dibukit Marwa dilakukan pembimbing yang diaminkan seluruh jama'ah bimbingan serta dilanjutkan dengan bertahalul dengan saling memotongkan rambut. Tujuh, membimbing jamaah perempuan jika datang haid atau nifas sebelum melakukan thawaf rukun (thawaf ifadhah), dan tidak 
memungkinkan menetap di Makkah untuk menunggu datangnya suci, maka kepada wanita seperti ini diberikan dua jalan keluar, yaitu: pertama, langsung berangkat dari Makkah tanpa melakukan thawaf, lantas ketika telah sampai pada satu tempat yang sukar untuk kembali lagi ke Makkah darinya, maka mereka bertaballul di sini, sama seperti orang yang tertawan. Sedangkan thawaf tetap wajib dalam tanggungannya. Kedua, melakukan thawaf dalam kondisi haid atau nifas dengan cara ber-taqlid kepada Abu Hanifah atau Ahmad ibn Hanbal, yang berpendapat boleh bagi wanita seperti ini melakukan thawaf, dengan resiko menanggung dosa serta wajib menyembelih satu unta. Berdasarkan pendapat ini, maka terlepaslah zimmah wanita ini dari kewajiban thawaf. (Wawancara dengan Divisi Haji dan Umrah PT. Noor Abika Tour Travel "Bapak H. Asep Komarudin" pada tanggal 20 September 2016)

Dalam pelayanan PT. Noor Abika Tour Travel memiliki standar pelayanan yang sudah mencapai standarnya. Pelayanan adalah memberikan apa yang telah dibutuhkan oleh para jamaah haji selama mereka menjalankan ibadah haji baik ketika masih di tanah air maupun di tanah suci. Diantaranya: Pertama, memberikan petunjuk kepada calon jama'ah haji tentang teknis, cara dan proses pendaftaran haji dengan segala syarat-syaratnya. Kedua, membantu atau mengantar setoran biaya perjalanan ibadah haji ke Bank yang ditunjuk pemerintah dengan membayar uang muka sebesar US\$ 4.500. Ketiga, membantu calon jama'ah haji dalam pemeriksaan kesehatan, pelayanan kesehatan merupakan pemeriksaan, perawatan, dan pemeliharaan kesehatan jama'ah haji. Keempat, memberikan bimbingan manasik haji secara lengkap dengan berpijak pada pedoman dari Kemenag dan tambahan dari pedoman PT. Noor Abika Tour Travel. Kelima, perjalan berangkat sampai pulang pada saat pelaksanaan ibadah haji yaitu transportasi merupakan pengangkutan jama'ah haji mulai dari tempat embarkasi, selama berada di Arab Saudi dan pemulangan kembali ke tempat debarkasi asal Indonesia. Keenam, memberi petunjuk tentang barang bawaan dan cara pengemasannya untuk di tanah suci dan pulang ke anah air. Ketujuh, penyampaikan bimbingan manasik haji baik secara lisan ataupun praktek. Kedelapan, tempat bimbingan lisan atau teori dan praktek di aula PT. Noor Abika Tour Travel sedangkan prakteknya di halaman kantor PT. Noor Abika Tour Travel. Kesembilan, membantu menguruskan barangbarang jama'ah haji yang tersesat atau hilang, sebelum berangkat maupun setelah kembali di Tanah Air.

\section{Evaluasi Pelayanan PT. Noor Abika Tour Travel}

Evaluasi atau penilian merupakan tahap trakhir yang di mana suatu perusahaan untuk menilai suatu pekerjaan yang sudah di lakukan oleh para karyawan.

Analisis Evaluasi Haji Plus Berdasarkan Pelayanan Prima. Analisis pelaksanaan ibadah haji plus berdasarkan pelayann prima pada PT. Noor Abika Tour Travel, yaitu analisis reabilitas, analisis daya tanggap, analisis jaminan, analisis empati, dan analisis bukti fisik.

Pertama. Analisis Reabilitas (Reability) diantaranya: Pertama, Pelayanan 
pelayanan dalam kelengkapan administrasi. Didalam kelengkapan administrasi ada kesinambungan antara pihak pengelola denga calon jamaah haji plus. Pihak travel berusaha sebaik mungkin memberikan kemudaha kepada calon jamaah haji plus tanpa jamaah harus bolak balik kembali travel. "karena memang kebanyakan dari calon jamaah kami adalah orang tua yang sudah berusia lanjut" pengakuan dari H. Asep Komarudin selaku Divisi Haji dan Umrah. Kelengkapan administrasi dan layanan yang baik disesuaikan dengan harga yang kami sudah tawarkan. Kedua, pelayanan informasi yang di terima. Memberikan informasi adalah salah satu faktor perjalanannya komunikasi antara pengelola dengan pelanggan, dengan informasi yang mudah diterima maka akan memudahkan calon jamaah haji plus. Informasi dari awal hingga akhir, seperti informasi proses pendaftaran, informasi kapan diadakan bimbingan atau manasik, informasi apa saja yang perlu di persiapkan, informasi kapan pemberangkatan dan informasi kapan pemulangan. Ketiga, pelayanan bimbingan yang sopan, ramah, baik dan siap menolong dalam melaksanakan ibadah haji plus. Untuk pelayanan dan bimbingan yang sopan, ramah, baik dan siap menolong dalam pelaksanaan ibadah haji plus, ini berarti pihak pengelola harus memberikan pelayanan dan bimbingan yang sopan, ramah, baik, dan siap menolong dalam pelaksanakan ibadah haji plus. Dalam bimbingan pihak pengelola mengambil ustadz dan ustadzah yang sudah berpengalaman dalam melaksanakan ibadah haji dan umrah. Di Arab Saudi pun kami sudah siapkan Mutho'if ( Orang yang membimbing pelaksanaan ibadah haji dan umrah). Jadi calon jamaah tak perlu khawatir, karena kami akan memberikan bimbingan serta layanan yang semaksimal mungkin dalam pencapain prosesi ibadah yang baik dan khusu'. (Wawancara dengan Bapak Asep Komarudin Pada Tanggal 20 September 2016)

Kedua. Analisis daya tanggap (Responssiveness) diantaranya: Pertama, karyawan melayani dengan sigap yaitu melayani dengan sepenuh hati. Apa yang diperlukan calon jamaah, apa yang dibutuhkan calon jamaah. Bertanya pada pelanggan adakah yang kurang dalam kami melayani atau adakah sesuatu yang di inginkan. Oleh karena itu jamaah yang kami bawa memang rata-rata sudah berusia lanjut, biasanya orang yang usia lanjut akan kembali sikapnya seperti anak-anak pada umumnya, ingin dipahami, ingin di mengerti dan ingin selalu di dengar. Kedua, karyawan melayani dengan tangkas berpikir cepat dalam mengambil keputusan. Dalam melayani karyawan harus baik dan cepat tanggap apa yang diinginkan oleh pelanggan (costumer), karena jika karyawannya lamban maka provit travel juga jadi menurun. Karyawan yang melayani dengan tangkas adalah faktor yang sangat penting bagi jamaah haji, karena jamaah yang banyak bisa langsung diatasi dengan adanya karyawan yang melayani dengan tangkas ini. Biasanya permintaan jamaah mengenai kosumsi, contoh "besok menunya ganti ya, pakain ikan asin saja." Memang umumnya jamaah lebih suka makanan khas Indonesia. Ketiga, pelayanan dengan transaksi pembayaran yang cepat. Pelayanan dengan transaksi pembayaran yang cepat adalah faktor penting bagi calon jamaah. Karena memudahkan dalam bertransaksi dan juga proses dalam kelengkapan administrasi. Jika administrasi sudah lengkap, mudah bagi kami untuk mempercepat membuatan paspor bagi 
yang belum memiliki. Dalam proses transaksi pembayaran yang cepat, mudah, dan praktis. Akan memudahkan bagi calon jamaah haji untuk memcapai peribadatan di negeri Saudri Arabia. (Wawancara dengan Bapak Asep Komarudin Pada Tanggal 20 September 2016)

Ketiga. Analisis jaminan (Assurance) :Satu, pengetahuan dan kecakapan petugas atau bimbingan haji dalam teori dan pelaksanaannya ditanah suci. Pengertian dari faktor ini adalah petugas atau pembimbing mempunyai pengetahuan baik yang menyangkut ( ilmu pengetahuan) dan pengalaman lapangan tentang pelaksanaan ibadah haji. Dari mulai dari persiapan pemberangkatan sampai pelaksanaannya ditanah suci. Di dalam bagian ini pengetahuan dan kecakapan petugas atau pembimbing haji dalam teori dan pelaksanaannya begitu sangat penting bagi jamaah haji. Karena ini adalah jaminan (Assurance) terhadap keberhasilan ibadah haji ditanah suci. Dua, kelancaran komunikasi antara sesama jamaah haji dan dengan petugas atau pembimbing. Untuk memperoleh dan mempertahankan totalitas para jamaah haji, maka harus dilakukan suatu komunikasi yang baik, efektif dan continue (bersambung) dengan para jamaah haji, guna menciptakan keunggulan pelayanan dan daya asing. Salah satu upaya yang jelas dari masalah tersebut adalah dengan mendengarkan apa yang diinginkan oleh para calon jamaah haji dan memberikan pengertian yang jelas mengenai kemampuan dari pihak pengelola dalam melayani semua jamaah. Dengan adanya komunikasi yang baik maka akan terjalin pula kerja sama yang baik antara para jamaah haji dengan pengelola. Karena sesuatu itu bisa di bangun dan di bantu oleh komunikasi yang baik dan terarah agar tidak terjadi kesalah pahaman antara para jamaah haji dengan pihak pengelola. Tiga, sertifikat haji. Sertifikat ini akan di berikan pada pemulangan di tanah air berbarengan dengan di bagikannya air zam-zam dan koper besar. Jamaah tak perlu merasa khawatir tidak dapat karena faktor ini adalah sangat penting bagi jamaah dan pihak penyelenggara memang sudah seharusnya memberikan itu.

Keempat. Analisis empati (Empathy) :Satu, memberikan perhatian secara individu dan kelompok dari jamaah haji. Kemampuan pihak penyelenggara untuk dapat memenuhi keinganan dan kebutuhan para jamaah haji merupaka suatu nilai tambah bagi pihak penyelenggara tersebut, dimana pihak penyelenggara dapat mengamati dan mengeti semua kebutuhan dan keinginan dari jamaah haji. Peningkatan kemampuan para pembimbing dan petugas haji untuk dapat memahami kebutuhan jamaah haji melalui pelatihan dan pertemuan serta dialog. Dua, bertanggung jawab terhadap keamanan dan kenyamanan jamaah haji. keridhoan Allah SWT yang telah mengupayakan travel ini berdiri Rasa aman merupakan suatu yang sangat diperlukan oleh setiap orang, bagi pihak penyelenggara hal ini menjadi sebuah keharusan untuk membrikan pelayanan bagi para jamaah haji. Bertanggung jawab dengan apa yang telah di rencanakan pada program awal, memberikan keamanan dan kenyamanan kepada para jamaah haji agar mereka bisa beribadah dengan tenang dan tanpa adanya rasa khawatir atau was-was dalam menuju atau mengunjungi baitullah (Rumah Allah). Karena ibadah 
haji ini tidak hanya mencari uang semata akan tetapi mengharapkan dan bejalan hingga sampai sekarang.

Kelima. Analisis bukti fisik (Tangibles) : Satu, mendapatkan buku panduan. Buku panduan adalah faktor penting bagi jamaah para jamaah haji, buku panduan adalah salah satu perlengkapan yang harus dimiliki oleh para jamaah haji, agar mereka bisa mengikuti dan membaca pada waktu bimbingan dan pelaksanaan seputar ibadah yaitu thawaf, sa'i, tahalul dan bercukur. Di dalam buku panduan itulah doa-doa akan di baca pada tempat-tempat peribadatan dan ziarah-ziarah seputar Mekkah dan Madinah. Dua, mendapatkan perlengkapan seragam, kain ihram dan mukena. Perlengkapan lain yang di butuhkan jamaah haji adalah perlengkapan seragam karena seragam akan memudahkan Tour Leader dalam membimbing, karena dengan identitas yang sudah dikenali dari sudut meskipun dengan jarak yang jauh. Kain ihram adalah kebutuhan yang di perlukan bagi kaum jamaah haji laki-laki karena untuk prosesi dalam melaksanakan ibadah haji. Mukena adalah kebutuhan yang diperlukan bagi kaum jamaah haji perempuan karena untuk prosesi dalam melaksanakan ibadah haji.

Tiga, tempat tinggal (hotel atau pemondokan) dekat dengan pusat atau sarana ibadah. Tempat tinggal atau pemondokan merupakan pilihan yang sangat peka bagi jamaah haji, karena jauh tempat tinggal akan mempengaruhi pada setiap kegiatan rutinitas dalam pelaksanaan iabadah, baik di Madinah maupun di Mekkah. Di dalam bagian ini faktor tempat tinggal atau hotel adalah akomodasi yang begitu penting bagi calon jamaah haji, dalam pelaksanaan ibadah haji biasanya pihak penyelenggara akan memesan hotel yang dekat dengan sarana ibadah yang akan di tempuh oleh jamaah haji.

Empat, kelengkapan fasilitas dan sarana yang diperlukan oleh jamaah haji. Untuk memberikan pelayanan yang baik bagi jamaah haji, maka pihak pengelola memberikan kelengkapan pendukung dan penunjang yang di butuhkan oleh jamaah haji. Lima, kesiapan team medis (dokter), obat-obatan dan kosumsi dengan menu Indonesia. Situasi di Arab Saudi, khususnya Mekkah dan Madinah sungguh sangat berbeda dengan tanah air Indonesia yang beriklim tropis. Perbedaan tersebut terlihat pada letak Geograpis, penduduk, alam, lingkungan, suhu atau temperatur dan sebagainya. Untuk itu akibat perubahan tersebut bagi jamaah haji sangat memungkinkan timbulnya gangguan pada sistem metabolisme tubuh jamaah haji.

Tujuh, transportasi setiap kegiatan menggunakan bus AC. Penyedian alat transportasi dalam setiap kegiatan merupakan kebutuhan yang sangat vital bagi setiap jamaah haji, dan hal ini merupakan pilihan dari setiap jamaah haji. Transportasi bus ber ac tersebut digunakan di Madinah, Mekkah dan Jeddah serta kegiatan ziarah ke tempat-tempat yang bersejarah sudah menjadi keharusan bagi setiap jamaah haji. Untuk itu alat transportasi adalah alat pendukung utama yang disediakan oleh pihak pengelola PT. Noor Abika Tour Travel. (Wawancara dengan Bapak Asep Komarudin Pada Tanggal 20 September 2016).

\section{PENUTUP}


Berdasarkan analisa dan dari data yang diperoleh diambil kesimpulan: Pertama, perencanaan pelayanan prima PT. Noor Abika Tour Travel dalam pelayanan prima, PT. Noor Abika Tour Travel menggunakan strategi manajemen yang meliputi: Satu, perencanaan pengembangan prodak. Dua, penerapan harga. Tiga, pengembangan pasar. Kedua, penerapan pelayanan yang dilakukan P'T. Noor abika Tour Travel pada calon jamaah haji dalam menyelenggarakan pelayanan prima, penyelenggaraannya dilaksanakan sebagai pelayanan yang tepat dan efektif, sehingga dalam pelaksanaan kegiatan berjalan dengan lancar sesuian dengan tujuan yang telah ditentukan: Satu, dasar penyelenggaraan ibadah haji khusus (PIHK). Dua, fasilitas. Tiga, pembinaan di tanah air dan di tanah suci. Ketiga, evaluasi pelayanan dalam PT. Noor Abika Tour Travel berdasarkan pelayanan prima, PT. Noor Abika Tour Travel ini telah menerapakan prinsip-prinsip pelayanan prima. Hal ini dapat dilihat dari: Satu, analisis reabilitas (Reablility). Dua, analisis daya tanggap (Responssiveness). Tiga, analisis jaminan (Assurance). Empat, analisis empati (Empatby). Lima, analisis Bukti Fisik (Tangibles).

Dari uraian tersebut di atas, maka disampaikan beberapa saran yang sekiranya dapat memberikan manfaat bagi pihak penyelenggara ibadah haji khusus dan umrah, khususnya pengelola PT. Noor Abika Tour Travel dan pihak-pihak yang terkait dalam penyelenggaraan haji dan umrah. Adapun saran tersebut adalah: Pertama, hendaknya pihak penyelenggara mempunyai organisasi atau perkumpulan alumni haji dan umrah untuk mempererat tali silaturahmi jamaah sesama jamaah, maupun jamaah ke pihak travel PT. Noor Abika Tour Traveldengan mengadakan perkumpulan. Kedua, salah satu bentuk pelayanan yang modern adalah pihak pengelola membuat aplikasi di Android maupun Apple dan sebagainya, berupa profil PT. Noor Abika Tour Travel, alamat kantor agar memudah bagi calon jamaah dalam mengakses dan menerima pendaftran secara online ataupun melihat-lihat prodok yang ingin ditawarkan. Ketiga, diharapkan pihak penyelenggara haji dan umrah lebih meningkatkan pelayanan jamaah haji untuk mendapat kepercayaan masyarakat.

\section{DAFTAR PUSTAKA}

Barata, A.A. (2003). Dasar-Dasar Pelayanan Prima. Jakarta: PT. Granmedia.

David, F.R. (2009). Strategi Managemen. Jakarta : Salemba Empat.

Herdiansyah, Haris. (2011). Metode Pelatihan untuk Ilmu-ilmu Sosial. Jakarta : Salemba Empat Humanika.

Rosadi, A. (2013). Sejarah, Perkembangan dan Pemikiran Pengelola Ibadah Haji di Indonesia. Bandung : CV Arfino Raya.

Sadiah, D. (2014). Metode Penelitian Dakwah. Bandung : Mimbar Pustaka.

Saefudin, B. 2006. Manajemen Bimbingan Pelaksanaan Haji, Umrah dan Ziarah. Bandung.

Saladin, D. (2011). Manajemen Strategik. Bandung : Agung Ilmu.

Siagian, S.P. (2011). Manajemen Stratejik. Jakarta : PT. Bumi Aksara 
Ainurrohmah, Sitty Sumijati, \& Moch. Fakhruroji

Sugiyono. (2013). Metode Penelitian Kuantitatif, Kualitatif, dan R\&D. Bandung : Alfabeta.

Sutopo, S. (2003). Pelayanan Prima. Jakarta : Lembaga Administrasi Negara Republik Indonesia.

Umar, H. (2004). Metode Penelitian untuk Skripsi dan Tesis Bisnis. Jakarta : Raja Grapindo Persada.

Winarsih, A.S.R. (2013). Manajemen Pelayanan : Pengembangan Model Konseptual, Penerapan Citizens dan Standar Pelayanan. Yogyakarta : Pustaka Pelajar.

Syamsudin, RS. (2009) Strategi dan Etika Dakwah Rasulullah SAW. Ilmu Dakwah: Academic Journal for Homiletic Studies. 4.14: 793-808 